\title{
The 'crisis' in defined benefit corporate pension liabilities Part II: Current solutions and future prospects
}

Received (in revised form): 14th December, 2006

\section{Gordon L. Clark}

is the Halford Mackinder Professor of Geography at the University of Oxford and Professorial Fellow of St Peter's College, Oxford. He is also a senior research fellow at Harvard University's Labor and Worklife Program. The author of Pensions and Corporate Restructuring in American Industry (Johns Hopkins University Press 1993), Pension Fund Capitalism (Oxford University Press 2000) and European Pensions \& Global Finance (Oxford University Press 2003), he is the co-editor of The Oxford Handbook of Pensions and Retirement Income (Oxford University Press 2006).

\section{Ashby H. B. Monk*}

is a PhD candidate at Christ Church College, University of Oxford. His doctoral research focuses on the impact of competitive strategy and globalisation on the design and implementation of corporate benefit systems. He holds graduate and undergraduate economics degrees from the Sorbonne (Paris I) and Princeton University, respectively.

\begin{abstract}
Once an integral component of company-sponsored compensation schemes in many Western economies, private defined benefit (DB) pensions are in decline. For many, DB schemes (and their related healthcare liabilities, depending on the jurisdiction) have hobbled the financial wellbeing of plan sponsors and even whole sectors of industry. If a constraint on shareholder value in the short term, these schemes threaten long-term corporate survival in the emerging global economy. While there remains considerable debate over the ability of financial markets to adequately price DB liabilities, there is a growing industry devoted to estimating their long-term risks with respect to longevity, inflation and cost. In part I of this two-part paper, we surveyed the nature and significance of the problem, focusing upon the UK and the US private employer-sponsored plans. We suggested that the 'crisis' was apparent, for those willing to look, a decade ago. Its significance was papered over by the 1990s stock market bubble and high interest rates but has returned through what many analysts identify as a 'perfect storm'. Having documented the nature and scope of the 'perfect storm', we now evaluate in part II the proffered solutions to the crisis, such as financial engineering, government intervention and private sector negotiation. In the final sections of the paper, we set out the principles that should guide the design of new kinds of employer-sponsored plans noting that if, as suggested by many experts, Western economies are entering an era of increasing labour shortage, private pensions will continue to have an important role in managing human capital. Pensions (2007) 12, 68-81. doi:10.1057/palgrave.pm.5950045
\end{abstract}

Keywords: Pension crisis, finance, solutions, future prospects

\section{Introduction}

Once an integral component of companysponsored compensation schemes in many Western economies, defined benefit (DB)

*Correspondence: Ashby Monk, Oxford University Centre for the Environment, South Parks Rd., Oxford OX1 3QY, UK.

E-mail: ashby.monk@chch.ox.ac.uk pensions have hobbled the financial wellbeing of plan sponsors and even whole sectors of industry. In part I of this paper, we demonstrated that while asset management, actuarial and accounting shortcomings set the stage for the 'perfect storm', the actual impetus for the present 'pension crisis' was more complicated (see Managing The Burden 
and Market Failure). Indeed, given the tumultuous nature of capitalism, the inherited DB institution is constraining firm renewal and renovation necessary for success in the modern global economy. DB plan sponsors are tied to the past, forced to face the future with inefficient and outdated organisational structures and competitive strategies (see Scope of the Problem).

We now turn in part II to the proffered solutions to the pension crisis. To begin with, we argue that the current toolbox of solutions, such as negotiated agreements between the implicated parties (next section), government regulation (section Framework for government intervention) and financial products structured to better match with liabilities (section Framework for a market solution) are inadequate. Subsequently, we show that the dearth of viable long-term solutions stems, in part, from an inability to reduce the high cost of DB pension obligations, since contributions must be high enough to pay for what may be decades of inactivity (section Reality check: Pensions are expensive). Finally, we argue that distributing the high cost of occupational pensions, in a manner that does not impact in unintended ways the core operations of the plan sponsor, is necessary (section The principles for a sustainable model). We conclude part II with a road map for plan sponsors intent on evolving towards less constricting pension provisions. In all cases, the path forward for the DB pension crisis should be a private-sector solution (perhaps facilitated by government interventions) that achieves a new pension structure in which workers, employers and shareholders share the pension cost (although perhaps not the pension risk) cooperatively and fairly for the benefit of all parties.

The section below builds on previous sections from 'Part I: The 'Crisis' in Defined Benefit Corporate Pension Liabilities: Scope of the Problem', previously published in Pensions.

\section{Framework for a negotiated solution}

\section{Negotiations require sacrifice}

In both the UK and the US, a resolution of the DB knot must be found for employers, employees, shareholders and even taxpayers. A 'natural' solution to the DB pension crisis would be contract renegotiation. For negotiations to succeed, however, each party needs to be willing to sacrifice, and the level of compromise required to restructure looming pension burdens does not seem readily available in today's environment. Indeed, in order to achieve a cost-effective negotiated solution to the crisis, private solutions require informational and bargaining-power symmetry as well as overcoming misaligned interests due to principal-agent problems, a tall order. ${ }^{1}$ The competing interests of legislators, shareholders, M\&A merchants, buy-out markets, private equity markets, insurance markets and workers (retired and active) threaten the prospect of negotiations. Sponsors are also responsible as they all appear very keen to push the liability forward to future generations of managers to deal with and, in the case of US sponsors, use bankruptcy courts as a bailout or as a means of controlling negotiations.

\section{Collective breakdown?}

One group will require the most convincing: organised labour. The unions' historical role in pension provision demonstrates that their agreement, in particular, is vital to a successfully negotiated outcome. The presence of organised labour in post WWII manufacturing industries drove the original widespread implementation of DB pensions. ${ }^{2}$ Although weakened, the unions have retained much of their bargaining power in those industries (if not beyond). ${ }^{3}$ As noted in Part I unionised workers in the US are roughly four to five times as likely to receive DB pension benefits as nonunionised workers. ${ }^{4}$ This should not be surprising, as unions tend to use their bargaining power to push wages above marketclearing levels. ${ }^{5}$ It is not our intention to attack unions, as academic research has also shown that unions may increase labour productivity. ${ }^{6-9}$ In any case, dismantling the traditional DB pension schemes will require some sort of union partnership and cooperation.

In the UK, of course, The Pension Regulator has assumed the role of 'honest broker' and is heavily involved in creating solutions for 
both plan sponsors and beneficiaries. This role includes being a 'crisis manager' for plan sponsors threatened by default or insolvency. Most importantly, however, The Pension Regulator also acts as 'facilitator' of financial market transactions where pension liabilities are a major consideration (see the Marconi and BAA deals). As such, The Regulator is viewed in the marketplace as an engaged third party rather than simply as a constraint on deal making. Finally, The Regulator only guarantees a fraction of the accrued benefit as compared to the Pension Benefit Guaranty Corporation (PBGC), which means all parties are more willing to make concessions.

\section{In search of a new model}

In order to make a fresh start and increase the likelihood of achieving successful negotiations, sponsors should be focused on both 'cost-cutting' and 'risk-cutting' (ie risk transfer). Traditional DB pensions will not be available to new employees for much longer without cost reductions. For new pension constructs to be sustainable and secure, however, they will need to distribute the risks inherent to DB pension plans in ways that are neutral with respect to corporate structure. One system often lauded in this context is in the Netherlands. We now turn to the Dutch occupational model for inspiration.

\section{Sustainable DB}

Jan Nijsen, CEO of ING, recently stated, 'The Netherlands may be the country with the highest likelihood of keeping a long-term sustainable defined benefit system. ${ }^{10}$ The Netherlands offers a flexible and transparent mandatory second pillar pension structure that has convinced some of its sustainability. According to the Dutch central bank, pension regulation should be strict enough to safeguard solvency, but not so restrictive as to interfere with optimal management policies. Additionally, it believes that overly severe funding rules would compound the trend for pension fund sponsors to reduce guarantees or switch to DC plans. ${ }^{11}$

\section{Rigid flexibility}

The Dutch system combines inflexible solvency requirements for guaranteed nominal pension rights with high levels of flexibility for conditional pension rights.

Rigidity. Dutch pension funds are required to maintain a funding coverage ratio of 105 per cent at all times. Any drop below this level of funding requires a resolution in one year. In addition, pensions need to build up a cushion of up to 130 per cent, which varies according to the risk profile of the assets in the portfolio. ${ }^{12}$ These are strict requirements that ensure firms will have enough capital to pay at least nominal benefits. This approach to securing the pension benefit can be explained by the fact that the pension regulator PVK (now integrated into the Dutch National Bank) also regulates the insurance industry.

Flexibility. Pension funds have recourse to three main tools with which they can affect their funding status: contribution policy, indexation policy and investment strategy. ${ }^{13}$ When in unfunded states, funds can require increased contributions, forestall the indexation of benefits and/or change the investment strategy. For conditional pension rights (indexed), funds are not required to reserve extra capital. While indexed benefits are encouraged (and are often provided), only nominal benefits are guaranteed. In addition, benefits are largely based on the average wage rather than on the final salary, reducing funds' exposure to wage inflation risks.

\section{A new hope?}

The Dutch model could be enlightening for regulators in the UK and the US facing DB pension crisis. Indeed, the flexibilities built into the Dutch DB pension deal give it a DC-like flavour; benefits paid are, in part, a function of contributions and investment returns, thereby reducing the risks on the sponsoring organisations. However, this is most likely to be the 'end-model' not to emulate. The dwindling organised labour movements of the UK and the US suggest that this would be difficult to achieve as social solidarity underpins the whole Dutch pension framework. ${ }^{14}$ Moreover, the nominal guarantee of benefits can still cause problems between stakeholders over how these guarantees 
should be valued and funded (see section, The principles for a sustainable model: neutrality).

\section{Framework for government intervention}

\section{Security above costs}

Outsourcing supplementary pension provision to the private sector, a desired goal of the UK and the US governments over the past 50 years (witness the significance of tax benefits on employee and employer contributions), needs to be undertaken with due regard to the distribution of costs and risks. ${ }^{15}$ The governments' current willingness to eliminate the possibility of default, however, has concentrated with plan sponsors both the costs and the risks of a DB plan. Interestingly, given the long history of occupational pension provision, the first serious foray into pension funding regulation was only in 1974 — the US Employee Retirement Income Security Act. Since that time, numerous regulations restricting pension provision have been passed across the OECD. Thus far, legislation has focused on improving the security of plans and protecting the rights of plan beneficiaries. ${ }^{15}$

Once again, we face a political turning point in which governments will be called upon to assist in constructing a 'new' private pension agreement. For example, the recent US Pension Protection Act overhauls pension funding rules and also seeks to avoid a government bailout of the beleaguered PBGC. ${ }^{16}$ The UK Pension Act of 2004, among other things, set up the Pension Protection Fund $(\mathrm{PPF})$ and The Pension Regulator, with the prospect of risk-related insurance premiums. Although the Dutch pension system is on firm ground, the FTK reform package requires fair value analysis for pension liabilities and assets. In addition, global accounting standards are likely to adopt pension valuation standards similar to the UK in order to increase transparency.

The need for DB pension reform must be reconciled with increases in market distortion and sponsor costs, including those associated with tighter funding rules and requirements. For example, increasing regulatory costs could lead to enormous impositions on already imperilled firms.
Indeed, the countercyclical nature of funding rules already poses a threat to DB sustainability, as companies must fund more in downturns, when they might not be able to afford it. So far, the UK and the US seem willing to increase benefit 'security' in spite of its constricting financial effects on sponsoring firms, tightening the 'knot of contracts' and reinforcing the prospect of a failure of the DB institution.

\section{Why the nuclear option is not desirable}

For firms facing this 'tightening' stalemate, the government bailout via bankruptcy in the US and via the PPF in the UK may appear to be the only way to proceed. In fact, the US airline industry provides a good example of this claim: in 2005, Delta, Northwest, United Airlines and US Airways all filed for Chapter 11 bankruptcy. American Airlines is the only legacy carrier that has not yet resorted to court-ordered restructuring. This, however, puts American Airlines at a disadvantage as its competitors are expected to exit Chapter 11 with healthier balance sheets and lower current pension costs. In effect, the current crop of companies emerging from Chapter 11 are in much better financial shape.

\section{Not desirable}

No firm should have a pension interest in declaring bankruptcy. But those with debilitating DB pension obligations are seemingly left with no other option. This is a difficult and undesirable path. If total liabilities are greater than assets (as is often the case for firms with large unfunded pension liabilities), bankruptcy usually results in bondholders ending up with shares, shareholders ending up with hardly anything, workers ending up with much lower benefits and wages and management's focus being drawn away from core business. The transaction costs are extremely high, and the brinkmanship associated with a bankruptcy proceeding is antithetical to negotiated agreements. There are numerous opportunities for hold-up or hold-out. ${ }^{17}$ Finally, the courts will not necessarily do an effective job of restructuring. Indeed, the courts are hardly pension negotiators by training and expertise. ${ }^{18}$ 


\section{Framework for a market solution}

\section{Wall Street solutions}

In the absence of a negotiated or government solution, innovative financial products and investment strategies are finding a home within the pension community. The eagerness of plan sponsors to change errant investment strategies of the late 1990s, combined with the prospect of increased balance sheet volatility due to markto-market pension accounting, has sparked widespread interest among DB pension funds in risk immunisation and liability management.

The pension plans, however, looking for long-term solutions to their pension woes in financial products may be disappointed. DB pension providers face many risks, some hedgeable and some not, all of which pose serious threats to pension health. ${ }^{19}$ The 'unhedgeables' have thus far been resistant to the financial community's attempts to mitigate them. There are examples of success, such as the December 2003 Swiss Re mortality catastrophe bond. ${ }^{20,21}$ But such successes are rare and matched by failures. ${ }^{22}$ Nevertheless, financial innovation is worth examining, as it will very likely be an intermediate stepping stone in the path to a long-term stable solution.

\section{Successful innovation}

Pension funds have been drivers of financial innovation for decades, as their asset management strategies have prompted the provision of complex financial products. See, for example, Zvi Bodie $^{23}$ : 'While the immunisation strategies of pension funds have spurred innovation in the fixed income securities markets, pension fund contingent immunisation and portfolio insurance strategies have created a market for options and financial futures contracts.' There is no doubt that the peculiar requirements placed on pension funds have been a driving force for financial innovation since the 1970 s. $^{24}$

Financial innovation continues today. For instance, pension funds are increasingly demanding swap and derivative strategies, as pension funds become more sophisticated consumers of investment advice. If implemented properly, swaps can hedge against various risks, ${ }^{25,26}$ such as interest rate changes. ${ }^{27,28}$

\section{Financial limitations}

Financial products also offer trustees and management 'stop loss' strategies, risk immunisation, decreased balance sheet volatility and more efficient use of pension capital. With the huge demand coming from pension funds, the underlying problem impeding a structured finance solution is supply (see 50-year Gilts and 30-year Treasuries, where yields are far lower than historical levels). The supply of these securities could increase as governments take advantage of cheap debt. If, however, we consider widespread implementation of strategies involving longevity or inflation-linked bonds, finding suitable supplies to serve the UK and the US DB pension universe seems highly unlikely. Swap contracts may offer more liquidity, but they are expensive. In addition, unfunded plans that implement these strategies are committed to making up most of their deficit with increased contributions - a displeasing prospect for shareholders.

In addition, despite high costs, these strategies do not eliminate all of the risks for the firm. Some of the 'unhedgeables' (mortality risk, inflation risk, etc) will remain in one form or another, leaving the sponsor vulnerable in the future. ${ }^{29}$ Consequently, sponsors allow for the possibility that they will be hampered in some new way in the future (just as few saw, 30 years ago, the problems DB pensions would cause today).

\section{Bulge business}

Investment banks stand to gain significantly from the increased trading volume in structured financial products; multi-billion-dollar swap deals are particularly lucrative. This trend has not gone unnoticed, as bulge bracket firms beef up their pension supervisory services to offer tailor-made pension solutions, and specialty investment shops, such as Integrated Finance Limited, ${ }^{30}$ are created to take advantage of this trend. The development of specialists is welcome, as they will no doubt push financial innovation and raise awareness within the pension universe. In order to be a part 
of the long-term solution to the DB crisis, however, specialists need to find innovative ways to sidestep capacity constraints and eliminate the 'unhedgeables'. Otherwise, any single financial product or strategy, no matter how successful it is on a client-to-client basis, is not a solution to the pension crisis.

\section{One time charge}

Financial instruments can only be partial solutions to the risks posed by DB pension obligations due to unhedgeable risks and capacity limitations (again making pension liabilities different from traditional debt). Therefore, plan sponsors, keen to avoid diverted cash flows and balance sheet volatility, are looking towards the bulk annuity market and insurance companies as a possible solution to their pension problems. ${ }^{31}$ The bulk annuity market is a unique type of outsourcing; companies pay insurers a premium for taking on their pension assets and liabilities and removing the latent DB pension risks from the plan sponsor. At present, however, this costly solution is only available to plans that have reached full funding.

\section{Risk takers}

In order for bulk annuities to have widespread appeal, supportive regulation, which eases the capital requirements of firms underwriting the business and clarifies the legality of the transactions, is required. This should create more liquid markets, as current conditions are unsatisfactory and anticompetitive. For example, the UK Office of Fair Trading investigated the bulk annuity market in 2005 after complaints of unfair pricing. ${ }^{32}$ At the time of writing, the UK market for bulk annuities remains restricted, with Prudential and Legal \& General writing almost all of the business. Logically, higher levels of competition among bulk annuity providers would lower costs to a more reasonable level. Encouragingly, this appears to be happening, as firms and high profile individuals are considering entering the market, including Aviva, Aegon, Mark Wood, Warren Buffett, Isabel Hudson, Hugh Osmond, Edmund Truell and numerous investment banks. Indeed, one managing director at a bulge bracket investment bank told us that he has the green light to acquire a pension fund; their only problem is pricing the deal. In addition, Retiree Benefits LLC is the first US firm to express interest in the US buy-out market, suggesting this market is primed for growth as well. These players hope to make profits by doing a better job than pension funds at managing the intersection between assets and liabilities.

Although expensive, they are a one-time charge that could eliminate the sponsor's risks. As such, via bulk buy-outs, traditional DB pension liabilities could be 'sold off' and new, more sustainable plans constructed. These transactions would facilitate institutional solutions we believe important (see conclusions). Ideally, this service would be offered to funded and unfunded plans (via pay down periods over a set number of years).

\section{A stepping stone}

Financial markets have a crucial role to play in resolving the pension crisis. This role, however, is not, as was hoped by some, the panacea to the pension crisis. Both investment banks and bulk players are seeking to carve out the DB pension risks and take them from the sponsor. This is a key stepping-stone and requires ongoing innovation (and regulatory support), as the transfer of risks will create an opening for change. The ultimate solution to the pension crisis is, however, what fills this opening, not what creates it.

\section{Lifelong charge}

Considering that no complete integrated solution exists, many DB sponsors feel obliged to ride out their pension troubles. One response is for sponsors to close their plan to new entrants and work the liability off over the long term. Closing underfunded plans, however, is not without risks, as the maturity of such plans accelerates without a stream of younger participants. In addition, mature plans typically have greater calls on corporate assets and revenues, due to the funding costs associated with participants as they approach retirement. Accelerating maturity also normally prompts a switch from riskier assets to 
lower-yielding safe assets. This switch often requires firms to contribute more in order to return plans to funded levels, putting more stress on plan sponsors and on the market for fixed income products. ${ }^{33}$ As such, freezing pensions with the goal of wearing down the liability over the long term is not an effective solution to the pension crisis; the burden of a mature closed DB pension could outweigh that of an open DB pension (depending on the circumstances of the plan sponsor). ${ }^{34,35}$ Consequently, the decision to close or freeze a plan must be taken in coordination with a well thought out immunisation and funding strategy (see conclusions).

\section{Corporate control}

Despite the media attention on pension deficits among FTSE 100 and S\&P 500 DB plan sponsors, hundreds and perhaps thousands of small- and medium-sized corporations are also being forced to cope with burdensome DB pension liabilities. These firms are in a difficult position, but there is a solution for these smaller plan sponsors that is unavailable to larger firms: traditional mergers and acquisitions.

As indicated in part I, sponsors of maturing DB plans sequentially make themselves less competitive each time they choose current DB contributions over current investment in the firm. Moreover, as funding rules are tightening and prospective pension deficits are significant, the current generation of managers is being forced to privilege contributions over investment. As such, for firms with DB pension deficits, corporate competitiveness, particularly on the international stage, could spiral downwards. Although this is an alarming prospect for managers of small firms, selling out may offer firms another 'solution' outside of bankruptcy courts.

Indeed, large corporations would have no problem acquiring small DB plan sponsors so long as the acquirer has a benefit plan and capital structure different from the target. If this is the case, the DB pension obligation could be easily managed as a very small piece of the capital structure of the new larger firm. ${ }^{36}$ Moreover, using immunisation strategies, the target could minimise its $\mathrm{DB}$ pension risks, making itself a relatively attractive target and facilitating more generous pricing of the deal. Such a deal would be welcomed by shareholders and employees, although managers would effectively be selling their jobs. Although this is an extreme 'solution', some firms will have no other private sector alternatives.

\section{Perfect storm III}

Just as interest rates and assets came together in 2001 and 2002 in a perfect storm that sent pension funding levels plummeting, some hope that a partnership of high interest rates and high asset returns could send plans back to fully funded levels, avoiding the costly prospect of achieving full funding with contributions alone. Currently, with short-term interest rates rising, and markets showing resilience, deficit levels have been gradually improving from the lows seen between 2003 and 2005. Before ushering in the inverse perfect storm however, one needs to remember how unlikely this outcome is, as asset markets typically react inversely to interest rates; when rates get too high, bond and equity markets suffer. Nevertheless, considering the perfect storm $\mathrm{I}$, it is not outside the realm of possibilities and should at least be considered by sponsors in scenario planning - particularly considering that sponsors who are keen to immunise their risk may be holding assets that, although better reflecting their liabilities, do not carry the risk premium necessary to ride a wave of asset growth out of DB pension underfunding.

\section{Reality check: Pensions are expensive}

\section{Affordability}

Coming to grips with the true cost of retirement is vital to constructing a sustainable pension deal. (See Box 1 in Appendix for PGGM's Innovative Fair Value model.) Simply stated, pensions and retirement are extremely expensive. Moreover, while negotiations offer a mechanism for sharing the risk burden, and financial products offer a way of hedging against some priceable risks, neither are effective at reducing current costs. Indeed, within a traditional DB pension, the 
PGGM is a Dutch sector pension fund for the healthcare industry. They are the second largest pension fund in the Netherlands (€70bn) and have used an innovative value based ALM methodology to create their fair value (FV) model, which can value all cash flows: future and contingent. The model relies on binary state-contingent pricing (ie up state vs down state), which means they believe that pension funds value high returns more in an underfunded state (low state) than they would in an overfunded state (up state). This stems from the idea that less value is placed on an additional dollar of wealth if one is already wealthy than if one is poor. Risks are thus a big piece of what PGGM is looking to price in this ALM model.

- Scenario 1:Adverse impacts of indexation: FV can be used to calculate the probability of reaching funding levels in the future. For example, in one scenario in which the funding ratio started at 100 per cent, with 60 per cent of assets in equities and 40 per cent in bonds, the model showed that full indexation combined with a contribution rate of 20 per cent resulted in a 19.8 per cent probability of falling into underfunded status, a level very likely to be too high for trustees. Moreover, when the model switches from full indexation of benefits to only nominal guarantees, the probability of underfunding falls to 9.7 per cent, a much more reasonable level for trustees, considering the starting point is already on the edge of underfunding.

- Scenario 2: Stakeholder value: In addition, the FV model affords PGGM the ability to examine how each change in contribution, indexation and investment policy will impact stakeholders. The results are fascinating: In one scenario, a fixed contribution rate of 9.9 per cent is shown to be more valuable to stakeholders than having a fluctuating contribution rate that averages 8.7 per cent. This seems illogical since the 8.7 per cent implies that on average the firm would pay less. However, as the variable contribution rate includes a risk of very high contributions in difficult years (exactly when a firm would prefer not to pay higher contributions), the stakeholder prefers the more expensive but consistent contribution rate.

PGGM's FV model will help pension funds conceptualise the true costs and risks associated with their pension obligation. This is an innovation that merits widespread implementation.

benefit remains inflexible and generous, a toxic mix.

\section{Atlas the titan}

As of the mid-1990s (the most recent data available from the US Bureau of Labor Statistics), in medium and large private establishments, only 3 per cent of employees with DB pensions were required to contribute to their DB pensions. ${ }^{37}$ Although this percentage has no doubt risen, given the extent of current underfunding, it nonetheless suggests that firms have had to shoulder a large portion of the increase in pension costs over the past decade. ${ }^{38}$ In the UK, DB contributions have increased from 15.8 per cent in 2002 to 22 per cent of earnings in 2005
(Association of Consulting Actuaries Pension Trends Survey 2005). ${ }^{39}$ Yet, the percentage paid by the employer has risen more than the portion paid through employee contributions (employers' portion is up by 5 per cent but employees' by just 1.2 per cent since 2002). This demonstrates the over-weighting of cost with the sponsor and the inability to meaningfully change contribution policies to meet the high cost of pensions.

Undeniably, the dearth of viable long-term solutions to the pension crisis stems in part from the inability to reduce the high cost of retirement. With the market returns on the asset pools no longer able to keep up with the generosity of benefits, contribution levels must be set high enough to avoid an unstable plan. As a first step, 
if $\mathrm{DB}$ pensions shared this cost more equitably between workers and plan sponsors in ways that were 'neutral' with respect to firm effects, then the system could conceivably function efficiently.

\section{Contributions before benefits}

While current negotiations between employers and employees focus heavily on benefit levels, perhaps a near-term 'solution' could be a new bargain over the correct contribution rate. Indeed, benefit levels are rendered irrelevant if insufficient cash is set aside for pension funding. Raising employee contributions is one possible step forward in sharing costs. For example, a benefit formula that increased employee contributions when wages go up (as would happen if employees are required to give a percentage of their salary) is an effective partial hedge for the sponsor against wage inflation. Moreover, as we note later on, linking a contribution increase when a pay raise is given is less painful for employees, rather than trying to increase contributions outright. ${ }^{40}$ In addition, 'cost sharing' contracts that last for five to ten years, in which contribution levels for plan sponsors are fixed, would decrease volatility and increase DB pension sustainability.

\section{Useful intervention}

Changing employee contributions is not straightforward. Even if the pension covenant would allow it, a change in contribution levels could breach the employment contract. ${ }^{41}$ Such considerations are serious, and they may restrict a firm's ability to act. In case of negotiationparalysis, collective welfare may be served if the government were to set contribution guidelines (rather than funding rules) for both employees and employers in a manner that shares costs. ${ }^{42}$

\section{Outlook}

DB pensions are inherently expensive and, as the first few years of this decade demonstrate, previous attempts to find shortcuts have ended in hardship. Understanding the true cost of pensions is important, and sharing the burden of that cost will be essential for future endeavours. ${ }^{43}$ Of course, simply implementing a hike in employee contribution rates does not remove the burden of the DB pension obligation (and the associated risks) from the firm. Nevertheless, understanding how contribution rates impact pension benefits will be necessary for the construction of an institutional solution.

\section{The principles for a sustainable model}

\section{A difficult path}

Highlighting the principles of sustainability is important, because solutions to the pension crisis are so difficult to find and justify to stakeholders. Below, we have listed five particularly important principles that will need to be incorporated in any viable solution.

\section{Pareto improvement}

The success of any institutional solution or reform relies on maintaining the firms' market competitiveness while minimising harm to employees. In evaluating the welfare of the employee, however, one must examine everything: quality of life, longevity, job security, early retirement, compensation, etc. In this context, if life is longer, and all other variables remain the same, the employee is better off; in contrast, the firm is worse off, as it has to support the employee's extended life without receiving anything in return. In order to achieve a Pareto improvement, the gain in longevity for the employee would have to leave the firm no worse off. As such, increased longevity should be paired with a longer working life or more flexible contributions and benefits. There are trade-offs to be made in this crisis in order to right the wrongs of the past decades and to achieve a feasible solution to the current dilemma.

\section{Untying the knot}

All DB sponsors will need to look for ways to 'untie the knot' and unravel the contracts. For those firms with high levels of unionisation, binding arbitration could be a way of avoiding bankruptcy. In addition, for those firms that can afford it, financial markets offer some effective options, such as bulk buy-outs. Many companies, however, hope that the way forward is a 
generational one, in which new employees are not offered DB pensions, and the inherited liability of DB schemes is worked off by those employees over the long term. Yet, letting the liability wind down is a slow process, and may take several decades. For firms facing stiff market competition and demands from shareholders, this may be too long.

\section{Good government}

Despite past misjudgments, governments still have a significant role to play in resolving the pension crisis. Without new regulations governing contributions and encouraging the formation of a market for bulk buy-outs, private sector solutions may be stymied; the remaining option is a bailout. Regulation should, however, encourage the provision of plans that are 'neutral' with respect to corporate structure and, more importantly, facilitate the transition of traditional $\mathrm{DB}$ pensions to something else. In addition, corporate compensation practices have changed as fast as corporate structure, suggesting that room needs to be left for compensation and benefit flexibility. Finally, and perhaps most importantly, because pension provision in the private sector is voluntary, regulations must not confuse the objectives of the firm, which would only result in nonprovision. ${ }^{44}$

\section{Neutrality}

Once traditional private sector DB pensions are gone, firms will need to take their pension design back to their compensation practices. Specifically, firms are increasingly calling for plans that share risk; but for 'risk sharing' to move pensions towards sustainability, it must only be a stepping-stone in the path towards 'neutrality'. Neutrality means that the pension plan does not impact the core operations of the business in unintended ways, which suggests that the risks, although not the costs, of the pension might have to fall on the employee (see Conclusions for more details). Collective risk sharing is highly complex. ${ }^{45,46}$ In traditional DB pensions, the only situation where conflict between stakeholders can be avoided, from a game theory perspective, is when funding is exactly 100 per cent, since outside of this equilibrium each party will attempt to 'win' the surplus or 'win' the right not to own the deficit. ${ }^{47}$ Thus, if employer-sponsored pensions are to remain, 'risk sharing' will not be a solution on its own, as each stakeholder will inevitably look to 'win'. Consequently, neutrality implies 'risk cutting', although not necessarily 'cost cutting', for the firm. ${ }^{48}$ In any case, the current convoluted risk structure needs to be untangled.

\section{Innovation}

Widespread institutional change is going to come from innovation, as new pension plan designs will ideally offer firms more sustainable options. For example, hybrid pension schemes are one mechanism of encouraging institutional innovation. Many firms see hybrids as a way to revitalise their DB plan structure. Indeed, hybrids are a better option than continuing with a 'renegotiated' traditional DB plan, although this depends on the institutional set-up in the country. Hybrids, such as cash balance plans, are regulated as if they are DB, but the assets and liabilities grow as if they are DC, with contributions and a promised return (usually some T-bill rate). The benefit is then paid as a lump sum, rather than as an annuity. ${ }^{49}$ In terms of advantages, hybrids offer a more even accrual rate than traditional plans. Also, they do not penalise job mobility. Hybrids also allow sponsors to communicate pension values to employees in a way that is very similar to DC, with account values and nominal accruals each year. Another benefit of hybrids is the abolishment of early retirement provisions that are typically part of the overly generous DB pension deal. ${ }^{50}$ Interestingly, even the American Federation of Labor and Congress of Industrial Organizations (AFL-CIO) and the Service Employees International Union have been investigating hybrid models in an effort to combat waning pension coverage. Hybrids are no doubt an innovative alternative to traditional DB pensions and a feasible institutional solution.

\section{Conclusions}

A past generation of managers has made commitments requiring urgent renegotiation 
in the present in order to avoid institutional failure in the future. This pension crisis is worsened by the fact that government regulations have provided misguided incentives and compounded the problem, neutering the possibility of achieving a private sector solution and making government bailouts a first-order choice. Bearing in mind that there is no "silver bullet' or cost- or risk-free solution to the pension crisis, a road map is still necessary so those firms faced with the burden of a DB pension can understand what is at stake and what choices are available. Plan sponsors will first need to evaluate their own situation in order to determine their final destination, as plan health will ultimately dictate what is available and possible. Nevertheless, we believe four broad reform/restructuring paths can be implemented:

\section{Plan A: Removal and replacement}

Plan A is the most complicated of the four options offered here as the DB plan has to be removed before it can be replaced. Moreover, in order to remove the pension, plan A relies on using solutions that have failed thus far - the hope would be that negotiations, government intervention and financial and insurance products can be successfully combined and implemented in innovative ways. Nevertheless, each firm must consider its own situation, as the path taken by a well-funded plan will differ from that of an underfunded plan. The road map below is intended for the underfunded pension plan, which suggests that some steps could be passed over by a healthy DB pension. Although we are aware of the heroic nature of this undertaking, we argue that this is not impossible and is still the best path forward out of the pension crisis. Each of these phases on their own is not an adequate solution, but together they offer a road map to the future:

(1) Contribute: Plan sponsors should start by re-negotiating contribution levels and/or benefit levels (government involvement will most likely be required in this first phase due to the many complications in renegotiating). DB pensions are simply too expensive and generous for the firm to shoulder the entire burden. Changing benefit levels or sharing the burden of contributions will help put precarious plans on a firmer footing. (This should not be seen as a solution in its own right: just as managers 30 years ago could not foresee the burden of the DB plan, it is also risky to leave 'renegotiated' traditional DB plans in place.)

(2) Immunise: Financial immunisation, although incomplete, will be a useful tool for firms looking to transition out of their traditional DB pension. The plan can be partially neutralised (possibly even to longevity risk if financial markets can innovate). Moreover, married with equitable contribution and benefit policies, the plan sponsor will not have to shoulder the burden of returning the plan to full funding alone. Also, this 'stop loss' strategy will keep plans from relapsing into underfunded status during transition towards closure.

(3) Close:The paradox of closing or freezing a DB pension is that it accelerates the maturity of the plan, which could then precipitate a crisis. Consequently, closure of the DB pension needs to be to be undertaken after having completed the first two steps above.

(4) Sell: Once the traditional DB pension is frozen or closed, it will open the door for removing the management of the plan from the sponsor. Currently, the bulk buy-out market is the best hope for removal of the plan's risks. Thanks to the contribution policy changes and the financial immunisation, the plan should be in good health. More importantly, this health should allow for a cheaper bulk buy-out as competition in the market for closed DB pensions will ideally be fierce (if government legislation that reinforces this is implemented).

(5) Replace: Once the DB pension is gone, the replacement is likely a DC type plan. ${ }^{51}$ Indeed, it was conceded at our recent conference on DB pension liabilities that DC has the most traction going forward in the private sector. As mentioned earlier, however, traditional DC pensions can cause as many problems for the employee 
as DB pensions cause for the employer. As such, new DC models are needed, and are being created. Lessons from behavioural economics have helped to increase the effectiveness of DC pensions at preparing workers for their retirement. This can involve auto-enrolment, which has been proven to increase participation from 49 per cent to 89 per cent. ${ }^{52,53}$ In addition, linking increased contributions with pay raises has proven to be an effective mechanism for increasing the rate of contributions. ${ }^{40}$ In addition to behavioural tricks, pooling of assets to reduce transaction costs and consolidation of management could both improve DC efficiency. The DC plan could also be married with a post-retirement mortality pooling plan that might provide some annuity such as benefits at low costs. ${ }^{54,55}$ Finally, some are pushing for DC pension models that use an 'auto-pilot' mechanism that, among other things, might adjust contributions and investment policies over time, or include a phased purchase of deferred annuities, in order to control for human errors commonly associated with DC plans. ${ }^{56,57}$ Whatever the shape it takes, DC, love it or hate it, is the future of pension provision for those firms that face fierce market competition.

\section{Plan B: Incremental change}

If the above solution is not feasible, then the DB pension should be changed incrementally over time. Hybrid pensions, which legally remain DB, can achieve neutrality with respect to corporate structure and represent a significant improvement vis-à-vis traditional DB pensions from the firm's perspective (see section, Reality check: Pensions are expensive). Today, roughly 25 per cent of the Fortune 1000 DB sponsors have a hybrid. ${ }^{50}$ The success of hybrids also demonstrates why the pension debate need not be polarised between final salary $\mathrm{DB}$ and noncontributory DC - there are feasible alternatives that occupy middle ground.

\section{Plan C: Multi-employer plans}

Multi-employer pensions offer sponsors unable to implement plans $\mathrm{A}$ and $\mathrm{B}$ an alternative to doing nothing. For example, in the DC environment, these plans have been quite successful at pooling together smaller plans into regional, industry or even national plans (see in particular Australia's superannuation scheme and the NAPF's Super Trusts proposal). These multi-employer DC schemes reduce costs due to efficiencies and scale, all the while maintaining a role for the employer in pension provision, an element we feel strongly about. Ideally, this concept could be applied to smaller DB plan sponsors. By gathering DB plans that individually struggle, a redistribution of risks and costs could achieve, although not perfectly, a sustainable pension. Although government intervention may be necessary in this instance, particularly to renegotiate contribution and benefit levels, this sort of a plan could use the Dutch system as the model for reform.

\section{Plan D: Nonemployer plans}

As the UK Turner Report proposed, and the UK White Paper on Pensions (May 2006) has recently endorsed, a nonemployer national programme could be an effective mechanism for preparing people for retirement, so long as it incorporates some of the above innovative DC characteristics. These nonemployer options are also gaining traction globally. In addition, Ambachtsheer ${ }^{56,57}$ has argued that his 'auto pilot' plan would also work as a nonemployer DC-type pension - one that addresses human and governance problems typical of employersponsored traditional DC schemes. While we agree with the premise of these plans (improving coverage rates and decreasing firm-based risks), we do not see this as a viable solution due to the simple fact that occupational pensions still serve a labour management purpose. Nevertheless, it is worth drawing people's attention to the possibility.

\section{Final thoughts}

The above solutions target neutrality with respect to corporate structure and are not in any way a demonstration of our ambivalence towards employee welfare. By contrast, in countries where labour is to become a scarce resource due to 
demographic challenges, in particular Western Europe, the UK and to some extent North America, pensions will be a vital component of labour attraction, management and retention. Thus, as these shortages approach, they reinforce the need for an effective and sustainable pension system for the benefit of all parties.

\section{Acknowledgments}

The support for this paper was provided, in part, by the Lupina Foundation (Toronto), the Transport Studies fund at Oxford and The British Academy, being drawn from a larger research project on pension fund and healthcare liabilities in the private sector. We thank Christ Church for partially funding necessary travel. Helpful comments at various stages on the project were made by Keith Ambachtsheer, Teresa Ghilarducci, Tessa Hebb, Divyesh Hindocha, Ian Mills, Courtney Monk, Michael Orszag, Dallas Salisbury and Roger Urwin. The results and interpretations reported are the sole responsibility of the authors; none of the above should be held to account for any errors, omissions or opinions expressed herein.

\section{References and Notes}

1 Ambachtsheer, K. (2005) 'Beyond portfolio theory: The next frontier', Financial Analysts Journal, Vol. 61, No. 1, pp. 29.

2 Sass, S. (2006) 'The development of employer retirement income plans', in Clark, G. L., Munnell, A., Orszag, M. (eds.) 'Oxford Handbook of Pensions and Retirement Income', Oxford University Press, Oxford.

3 One option for DB plan sponsors with high levels of unionisation is to offer employees cash buy-outs wherein the management attempts to seduce the employees into giving up their pension claims via generous lump sum settlements, as GM recently attempted. This, however, has yet to be proven effective and is also fraught with money management dangers for those blue-collar employees who accept the windfall.

4 Data according to US Bureau of Labor Statistics: see www.bls. gov for details.

5 McDonald, I. and Solow, R. (1981) 'Wage bargaining and employment', American Economic Review, Vol. 75, No. 5, pp. 896-908.

6 This has been debated in academic literature, with many arguing that unions increase productivity while others arguing that unions constrain innovation and lower profitability; see Freeman's ${ }^{78}$ seminal work on these issues, Doucouliagos and Laroche $\mathrm{e}^{79}$ for a summation of the literature and Hirsch ${ }^{80}$ for a demonstration of unions' impact on profitability.

7 Freeman, R. (1984) What do unions do?' Basic Books, New York.

8 Doucouliagos, C. and Laroche, P. (2002) 'Unions and productivity growth: A meta analytic review. GREFIGE Université Nancy 2, Cahier de recherché; 2002-02.
9 Hirsch, B. T. (2004) 'What do unions do for economic performance?' Journal of Labor Research, Vol. 25, No. 3, pp. 415-455.

10 Statement from IPE Netherlands, February 2006, p. 6.

11 Bikker, J. and Vlaar, P. (2006) 'Conditional indexation in defined benefit pension plans', DNB Working Paper; 86.

12 Based on preliminary FTK legislation, which is expected to come into effect in 2007.

13 Although some of these policy decisions are made on a yearly basis.

14 Reil, vD., De Deken, J. and Ponds, E. (2006) 'Social solidarity', in Clark, G. L., Munnell, A., Orszag, M. (eds.) 'The Oxford Handbook of Pensions and Retirement Income', Oxford University Press, Oxford.

15 Laboul, A. and Yermo, J. (2006) 'Regulatory principles and institutions', in Clark, G. L., Munnell, A., Orszag, M. (eds.) 'Oxford Handbook of Pensions and Retirement Income', Oxford University Press, Oxford.

16 The legislation will certainly strengthen the security of promised benefits for current employees and reduce the exposure of the PBGC. Owing to its increasing restrictions however, the bill will hasten the demise of traditional DB pension plans in the private sector.

17 Williamson, O. (1979) 'Transaction-cost economics: The governance of contractual relations', Journal of Law and Economics, Vol. 22, No. 2, pp. 233-261.

18 As noted above, the UK Pension Regulator has demonstrated that the 'nuclear option' is not necessarily the only path forward for managing pension liabilities.

19 Cardinale, G., Katz, G., Kumar, J. and Orszag, M. (2005) 'Background risk and pensions', in: Institute of Actuaries; 2005 November 28; London, United Kingdom.

20 The bond was constructed with principal that is unprotected and depends on what happens to an index of mortality rates across the United States, United Kingdom, France, Italy and Switzerland. Investors in the bond receive an enhanced return if mortality remains at normal levels. This issue was fully subscribed. For the issuer, life insurance is a primary source of business, accounting for roughly 30 per cent of turnover. Thus, profitability is negatively correlated with mortality rates, making this bond effective at shifting its longevity risk profile.

21 Blake, D., Cairns, A. and Dowd, K. (2006) 'Living with mortality: Longevity bonds and other mortality-linked securities', in Faculty of Actuaries; 2006 January 16; London, United Kingdom.

22 For instance, a 2004 Longevity bond by EIB and BNP Paribas failed to garner enough interest.

23 Bodie, Z. (1989) 'Pension funds and financial innovation', NBER Working Paper; 3101.

24 Clowes, M. J. (2000) 'The Money Flood: How Pension Funds Revolutionized Investing', Wiley: New York.

25 'See Bodie and Merton ${ }^{26}$ for a fascinating paper on pensions and swaps.

26 Bodie, Z. and Merton, R. C. (2002) 'International pension swaps', Journal of Pension Economics and Finance, Vol. 1, No. 1, pp. 77-83.

27 As mentioned by Hindocha on a previous draft however, there are limits to the extent of risk diversification in the market. Indeed, as Shiller ${ }^{99}$ points out, the only way to deal with concentrated risk is to have a global marketplace with a greater capacity to spread risk.

28 Shiller, R. J. (2003) 'The New Financial Order: Risk in the 21st Century', Princeton University Press, Princeton, NJ, Woodstock. 
29 Credit Suisse, however, has created a life index with which they hope to base financial products. They expect life assurors and pensions to be natural counter parties.

30 A specialist investment bank combining academic pension finance research (Robert Merton and Zvi Bodie) with derivative and investment banking specialists (Peter Hancock and Roberto Mendoza).

31 The prospect of a bulk buy-out market raises contentious legal issues; namely whether the liability can legally be transferred and who is responsible for the liability should the bulk annuity provider fail.

32 For plan sponsors keen to shed their liabilities, one strategy might be to combine the purchase of a bulk annuity with a purchase of the life insurers shares as the extra profits from the annuity sale would likely feed through into a dividend or appreciation over time.

33 Clark, G. L. (2006) 'The UK occupational pension system in crisis', in H. Pemberton, P. Thane and N. Whiteside (eds) 'Britain's Pension Crisis: History and Policy', Oxford University Press, Oxford.

34 In the UK rail industry, plans closed to new entrants have roughly 4 per cent higher employee contributions than open plans. $^{35}$

35 Taylor, A. (2006) 'Rail unions seek minister's aid as strike looms over pensions capping', Financial Times, 2006 March 7.

36 This will not work for large DB plan sponsors, since pricing and taking over a large pension liability becomes too much of burden on the acquirer.

37 Data according to US Bureau of Labor Statistics: see www.bls. gov for details.

38 Employees, however, could also be paying indirectly to some degree by foregoing increases in their current pay, despite the tax disadvantages of this strategy compared with direct employee contributions.

39 According to a survey of 392 DB plan sponsors with some $£ 131$ bn in assets; see www.aca.org.uk.

40 Thaler, R. and Benartzi, S. (2004) 'Save more tomorrow (TM): Using behavioral economics to increase employee saving', Journal of Political Economy, Vol. 112, No. S1, pp. 164-187.

41 UK regulations: How to boost contributions to final salary pensions. EIU ViewsWire. New York, May 27, 2003.

42 On a previous draft, questions were raised over whether this is the same as allowing corporations to renege on their promises if plan members do not accept to put more money into funds. We are not arguing to allow companies to default on promises. We argue that negotiation must be achieved outside of bankruptcy, so as to avoid court-managed distribution of the burden.

43 DB pensions are deferred pay plus an annuity, which implies that employees may receive more than just deferred compensation.

44 Clark, G. L. and Hu, Y. (2005) 'Re-writing pension fund capitalism 2: The UK pensions crisis and trends in occupational pension plan benefits, 1950-2004', Oxford University Working Papers in Employment, Work and Finance; 05-09.

45 Ambachtsheer, K. (2005) 'Taking the D out of DB', Benefits Canada, Vol. 29, No. 9, p. 49.

46 Drucker, P. F. (1976) 'Pension fund socialism', Public Interest, No. 42, pp. 3-46.

47 Ambachtsheer, K. (2002) 'A beautiful plan', Benefits Canada, Vol. 26, No. 10, pp. 19.

48 For a discussion of how DB pensions impact sponsors see the 'key findings and conclusions' from the Rotman International Centre for Pension Management conference on Pension Plan Design, Risk, and Sustainability (http://www.rotman.utoronto. ca/icpm/Workshop05_keyfindings.pdf).

49 Clark, R. and Schieber, S. (2004) 'Adopting cash balance pension plans: Implications and issues', Journal of Pension Economics and Finance, Vol. 3, No. 3, pp. 271-295.

50 Coronado, J. and Hewitt, G. (2005) 'Is there a future for defined benefit pensions in the United States?' Benefits Quarterly, Fourth Quarter.

51 This step could be set up earlier in anticipation of freezing, closing or removing the DB pension.

52 With respect to automatic enrolment, the recent US Pension Protection Act gave a strong endorsement for automatic enrolment, clearing up many of the legal issues that companies were concerned about.

53 Madrian, B. C. and Shea, D. (1999) 'The power of suggestion: An analysis of 401(k). Participation and saving behavior', University of Chicago Working Paper.

54 See paper by Urwin on the future of pensions.

55 Urwin, R. (2006) 'Constructing a lifelong deal for employees'. The future of pensions, Financial Times fund management 2006 March 27.

56 Ambachtsheer, K. (2006) 'Pension Revolution I', Financial Post, March 29, 2006.

57 Ambachtsheer, K. (2006) 'Pension revolution II', Financial Post, 2006 March 30. 